\title{
ON THE AMOUNTS OF MINOR ELEMENTS IN FINNISH SOILS
}

\author{
JOUKO VUORINEN
}

\author{
Agricultural Research Centre Department of Soil Science, Helsinki
}

Received December 12, 1957

In agricultural development one of the most certain increasers of productivity is the intensifying of fertilization. By the help of field and laboratory investigations, the nutrient condition of the cultivated field has been brought towards the correct balance in the best cases with regard to both the amounts of the different nutrients and the relation between them (7). In Finland we can already say that this is so in the case of the major nutrients in practical cultivation (8). From the point of view of the minor elements the situation is, on the contrary, still uncertain in many ways. A long "robbery" cultivation towards minor elements is a fact in agriculture nowadays. Besides this, the more intensive the cultivation is in other respects, the greater the "robbery" effect. The consequences are already to be seen in many places both in extensive and intensive plant husbandry, especially in sugar-beet cultivations and in gardens. The farmers are even overinterested in the minor element problem, and the blame for poor growth is often laid on the minor elements, although amelioration with lime or with the main nutrients has not been done.

Investigations to solve the minor element problems of the Finnish soils are being carried out in many ways. From fertilizing experiments in field conditions, the deficiency of copper and boron, for example, has already been proved and on using the corresponding fertilizers big increases in yield have been obtained $(5,6,3)$. The amounts of minor elements in the soil have been investigated spectrographically $(4,10)$, but questions such as the solubility of the minor elements in Finnish soils and the need for or the poisonous qualities of the minor elements still require much investigation.

\section{Material}

In the following a summary is given of the minor elements in Finnish soils, based on the results of analyses received up to the present. The material of the investigation consists of samples of surface soils, taken from the experiment fields used in minor element fertilization investigations, from experimental and school farms, and from fields belonging to private farmers. The analysis figures show the total concentrations of the minor elements. The determination has been done spectrographically (4). 


$\begin{array}{ccc}\text { Samples } & \text { Finnish soils (9) } \\ \text { in this investigation } & & \text { in general } \\ \text { Number of samples } & \% & \text { Number of samples }\end{array}$

in general

Number of samples $\quad \% \quad$ Number of samples $\quad \%$

$\begin{array}{lrrrr}\text { Moraine } & 248 & 6.8 & 5385 & 4.8 \\ \text { Sand } & 38 & 1.1 & 1590 & 1.4 \\ \text { Finesand } & 1030 & 28.9 & 29391 & 26.3 \\ \text { Silt } & 320 & 9.0 & 9164 & 8.2 \\ \text { Clay } & 723 & 20.3 & 38670 & 34.6 \\ \text { Gyttja clay } & 157 & 4.4 & 4270 & 3.8 \\ \text { Mould } & 511 & 14.4 & 12592 & 11.3 \\ \text { Carex peat } & 471 & 13.2 & 9396 & 8.4 \\ \text { Sphagnum peat } & 66 & 1.9 & 1373 & 1.2\end{array}$

The amounts of the minor elements vary considerably in the different soil types in Finland. However the distribution of the material (about 3500 samples) between the different soil types represents Finnish soils well (9), as the table above shows.

\section{Results}

The following average values (ppm metal in air-dry sample) have been obtained for the concentrations of the minor elements in Finnish field soils:

\begin{tabular}{|c|c|c|c|c|}
\hline $\begin{array}{l}\text { Minor } \\
\text { element }\end{array}$ & $\begin{array}{c}\text { In Finland } \\
\text { on an average }\end{array}$ & $\begin{array}{l}\text { In the ground } \\
\text { (1) }\end{array}$ & $\begin{array}{l}\text { In cultiv } \\
\text { Scotl } \\
\text { on granitic } \\
\text { ground }\end{array}$ & $\begin{array}{l}\text { ded soil in } \\
\text { on gneiss- } \\
\text { granite ground }\end{array}$ \\
\hline $\mathrm{Cu}$ & 21 & 70 & $<10$ & 25 \\
\hline $\mathrm{Ga}$ & 24 & 15 & 25 & 70 \\
\hline $\mathrm{Pb}$ & 16 & 16 & 20 & 70 \\
\hline $\mathrm{Zn}$ & 36 & 80 & - & - \\
\hline Co & 12 & 40 & $<2$ & 10 \\
\hline $\mathrm{Cr}$ & 87 & 200 & 5 & 200 \\
\hline $\mathrm{Mn}$ & 617 & 1000 & 700 & 1000 \\
\hline Mo & 4.5 & 2.3 & $<1$ & $<1$ \\
\hline $\mathrm{Ni}$ & 23 & 100 & 10 & 40 \\
\hline V & 183 & 150 & 20 & 250 \\
\hline
\end{tabular}

The average minor element content of the Finnish soil does not greatly differ from the minor element content of the earth's shell (1). Compared with Scottish cultivation soils (2), one can notice that in our field soils the concentrations of minor elements are of very much the same magnitude. The concentrations of some minor elements $(\mathrm{Ga}, \mathrm{Pb}, \mathrm{Mn}, \mathrm{Ni})$ correspond more with figures from the fields in the granite 


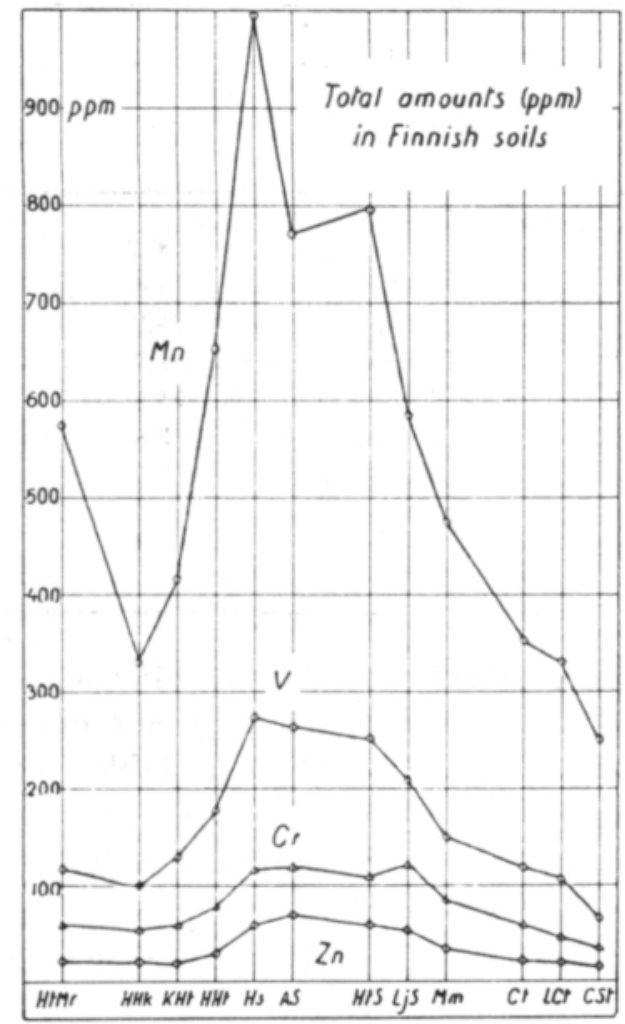

Fig. 1 - Piirros 1

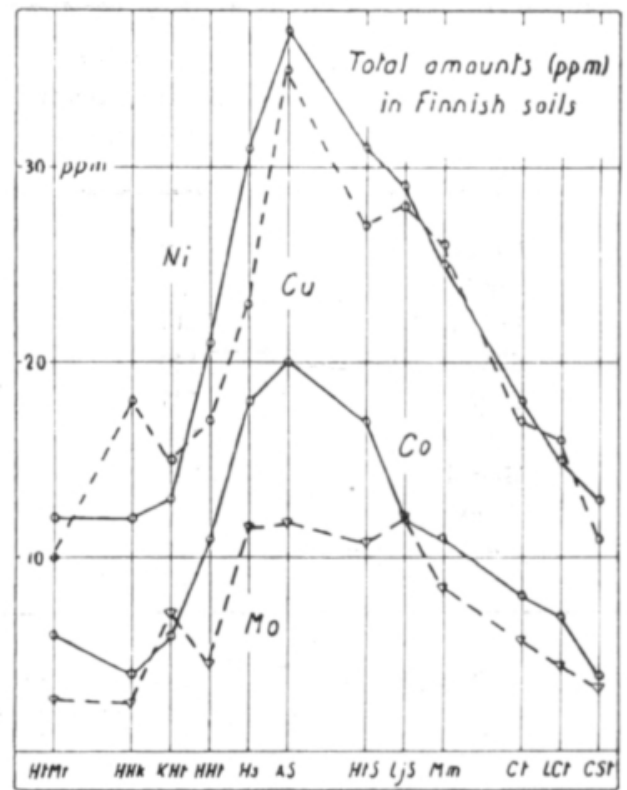

Fig. 2 - Piirros 2

$$
\begin{aligned}
\mathrm{HtS} & =\text { loamy clay } \\
\mathrm{LjS} & =\text { gyttja clay } \\
\mathrm{Mm} & =\text { mould } \\
\mathrm{Ct} & =\text { Carex peat } \\
\mathrm{LCt} & =\text { Ligno Carex peat } \\
\mathrm{CSt} & =\text { Carex Sphagnum peat }
\end{aligned}
$$

districts of Scotland, while the concentrations of others $(\mathrm{Cu}, \mathrm{Co}, \mathrm{Cr}, \mathrm{V})$ correspond better with concentrations in the soils in the gneiss-granite districts.

However, in the total amounts of the minor elements investigated there are very big differences to be seen between the soil series (Fig. 1 and 2).

\section{Discussion}

Scrutiny according to soil type shows that grain size and humus content are decisive factors in the total amounts of the minor elements (Fig. 1 and 2).

In sorted mineral soils especially the consequences of grain size can be noticed. All the minor elements investigated increase very clearly from the coarse soil types to the finer ones (HHk-AS,-sand-heavy clay, Fig. 1 and 2). Thus the amounts of the minor elements in heavy clay are multiples of the corresponding amounts in 

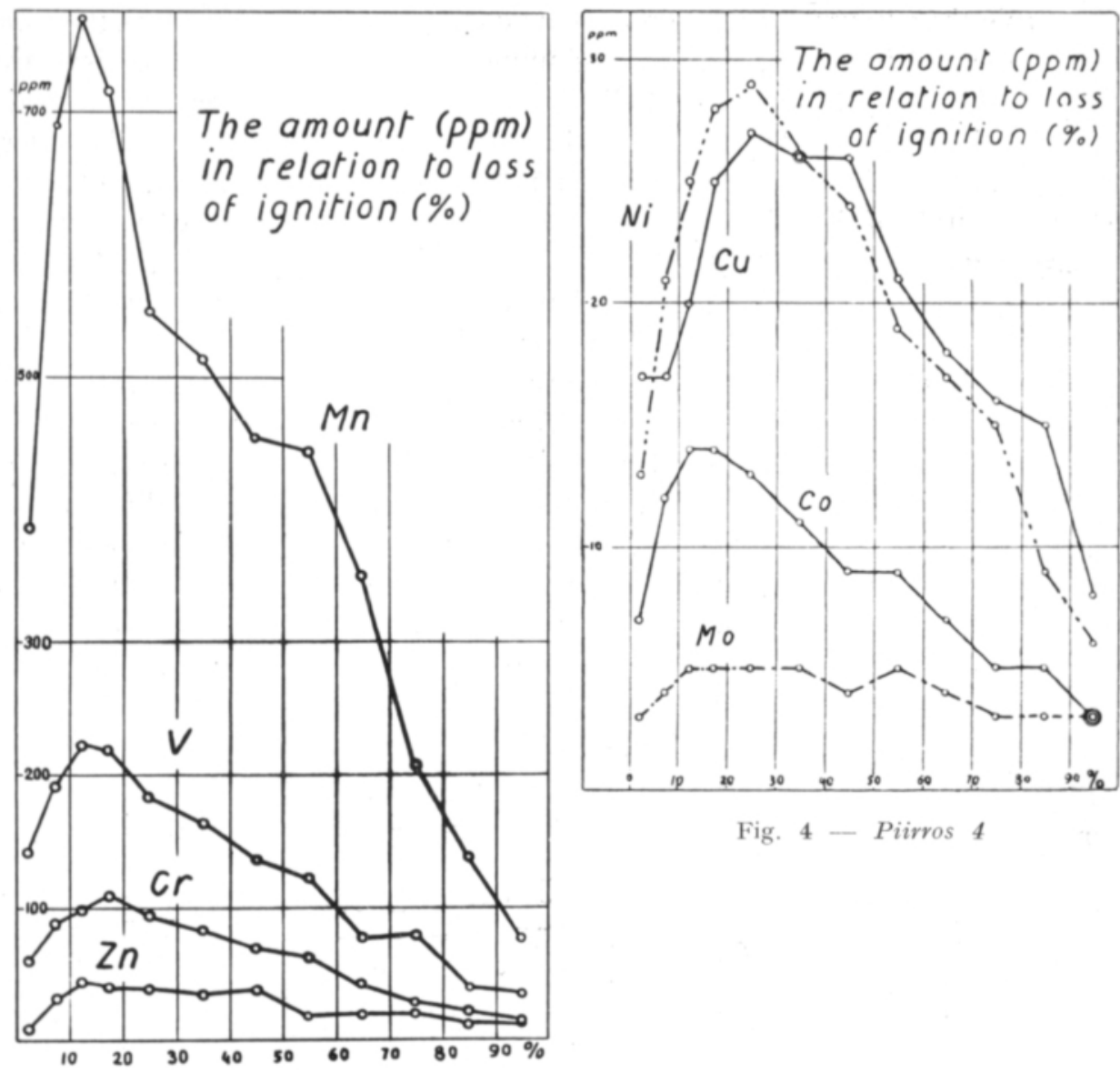

Fig. 4 - Piirros 4

Fig. $3-$ Piirros 3

sand-soils. For molybdenum and cobalt this difference is $4-5$-fold, for zinc more than threefold, for vanadium about threefold, for chromium and manganese it is more than twofold and for copper and nickel it is twofold. Accordingly, a heavy increase of minor elements in these sorted soils can be noticed as the soil becomes finer. It cannot be seen that the grade of fineness has the same effect in moraine soils.

The minor element content of the peat soils (Ct-CSt, - Carex-Carex Sphagnum peat, Figures 1 and 2) is very low and on the same level as in sand soil. Bog peat soils generally have a lower minor element content than Carex peat soils.

The youngest soils in our country, loamy clay $(\mathrm{HtS})$, gyttja clay $(\mathrm{LjS})$, gyttja $(\mathrm{Lj})$, mud $(\mathrm{Jm})$ and mould $(\mathrm{Mm})$ lie between glacial clay and peat soils as regards concentrations of the minor elements. On an average the amounts of the minor elements decrease in the order of the soil types mentioned above, from loamy clay to mould, which is also the main direction of increase in humus content. In this group the copper content is the highest ( $>26 \mathrm{ppm}$ ) and is fairly uniform. Only heavy clay contains more copper $(35 \mathrm{ppm})$ than these young soils on an average. Mud has the highest copper content (37 ppm). 
As a rule the amounts of the minor elements decrease (Fig. 3 and 4) as the humus content of the soil increases. In the beginning, when the ignition loss rises from $0-10 \%$ to $10-20 \%$ the amounts of all minor elements increase, because a considerable part of the loss consists of water, and actually the coarse mineral soils undergo a change, becoming finer. In the greater ignition losses (organic soils), on the contrary, the amounts of the minor elements decrease more or less regularly. For nickel this increase goes up to a $20-30 \%$ ignition loss and for copper up to a $40-50 \%$ ignition loss, which shows that humus evidently acts as a store for these substances.

When comparing the relations of the amounts of different minor elements with each other, it has been calculated how many $\%$ each of the ten investigated minor elements are out of their total amount. Manganese forms the main part $(600 \%)$ of these and its proportion is highest in moraine and lowest in gyttja clay. The proportion of vanadium is about $180 \%$ and its amount proportions in different soils are opposite to those of manganese. The proportion of chromium is about $80 \%$ rather equally in all soils. Only gyttja clay and mould contain comparatively more chromium. The proportional amount of zinc is $40 \%$ on an average. It is highest in heavy clay $(50 \%)$ and lowest in coarse soils and moraine $(25-30 \%)$. The average proportion of copper and nickel among the minor elements investigated is about $20 \%$ and it is highest in heavy clay, mould and peat soils. In moraine and coarse mineral soils the proportion of copper and nickel is distinctly the lowest. The proportion of cobalt is above $10 \%$ and that of molydenum below $10 \%$. Moraine and coarse mineral soils have the lowest contents with regard to these elements also.

The total amount of the ten investigated substances is highest in silt and silty clay soils (about $1600 \mathrm{ppm}$ ); in heavy and loamy clay it is about $85 \%$ of the above value, in fine sandy and loamy soils and in gyttja clay about $2 / 3$, in moraine and mould soils about $1 / 2$ and in peat soils about $1 / 3$ of the amounts contained by silt soils. The big store of the minor elements, as well as that of the main nutrients contained in silt soils, is certainly partly due to the bad physical conditions of the soils. Thus growth and yield are so poor that the nutrients stay in the soil unused.

The use of the important minor nutrients for fertilizing in different conditions, however, demands above all elucidation of the solubility questions with regard to these substances, which again is a comprehensive field in itself.

\section{REFERENCES}

(1) Goldschmidt, V. M. 1954 (ed. Murr, A.) Geochemistry. Oxford.

(2) Chemistry of the Soil 1955 (ed. BEAR, F. E.) I-X, 1-373. New York.

(3) HänNıNen, P. 1956. Observationer över inverkan av bor på rödklöverns fröavkastning i mellersta Finland. Ref. J. Vuorinen. Nord. jordbr. forskn. 38: 199-209.

(4) LAPPI, L. \& MÄкıтıЕ, O. 1954. Quantitative spectrographic determination of minor elements in soil samples. Acta agric. scand. 5: $69-75$.

(5) TA1Nıo, A. 1951. De hittillsvarande resultaten av undersökningar rörande mikroelementen i Finland. Nord. jordbr. forskn. 33: 287-291. 
(6) $\longrightarrow$ 1956. Koppargödslingens inverkan på timotejvallarnas avkastning i Finland. Ref. J. Vuorinen. Ibid. 38: $199-209$.

(7) Vuorinen, J. 1952. Koetilojen peltojen viljavuudesta. Summary: On the fertility of soils on experimental farms in Finland. Agrogeol. julk. 59: 1-59.

(8) $\rightarrow$ \& KURKI, M. 1955. Viljavuustutkimustulosten tarkennettu tulkintaohje. Maatalouskoelaitos, maatutkimusosasto. 4 pp. Helsinki.

(9) $\rightarrow 1955$ Nurmien viljavuudesta. Summary: On the fertility of grassland soils in Finland. Maatal. ja koet. 9: $23-37$.

(10) —— 1956. Finska undersökningar rörande $\mathrm{M}, \mathrm{Cu}$ och B. Nord. jordbr. forskn. 38: $199-209$.

\title{
SELOSTUS:
}

\section{SUOMEN MAALAJIEN HIVENAINEMÄÄRISTÄ}

\author{
JOUKO VUORINEN
}

\section{Maatalouden tutkimuskeskus, Maantutkimuslaitos, Helsinki}

Hivenravinteiden puutoksia on Suomessa todettu (5, 6. 3) lannoituskokeilla kenttäolosuhteissa. Toisaalta on hivenaineiden esiintymistä maaperässämme tutkittu spektraalianalyyttisesti (4. 10), mutta esim. hiventen liukoisuus Suomen maaperässä, hivenravinteiden tarve tai myrkyllisyys kasville on vielä monien selvitysten tarpeessa.

Tässä tutkimuksessa on esitetty tuloksia Maantutkimuslaitoksen aineiston spektrograafisista analyyseistä (n. 3500 näytteestä) tärkeimmistä maalajeista, joiden osuus tutkimuksessa on esitetty taulukossa. Eri hivenaineiden $(10 \mathrm{kpl})$ kokonaismäärät miljoonasosina $(\mathrm{ppm}=\mathrm{mg} / \mathrm{kg})$ on esitetty Suomen maaperää kuvaavina keskiarvoina. Toisaalta on näiden hiventen määrät eri maalajeissa esitetty piirroksissa 1 ja 2.

Tulokset osoittavat kivennäismaiden $\mathrm{r}$ a es u u u de n hyvin ratkaisevasti vaikuttavan hivenaineiden kokonaismääriin niin, että mitä hienommasta maasta on kysymys sitä suurempi on yleensä sen hivenainepitoisuus. Tämä suhde on esim. hienon hiekan ja aitosaven välillä kahdesta viiteen kertainen ja eri hivenaineilla erilainen.

Maan humuspitois u de 11 a on ilmeisesti huomattava merkitys hivenainevarastona. Tämä näkyy erityisesti piirroksissa 3 ja 4, joissa on esitetty maan hehkutuskevennyksen ja hivenainemäärän suhde.

Hivenaineiden k es ki nä is is sä s u h teissa todetaan mangaani päätekijäksi $(60 \%)$ kun taas muiden osuus tutkitun kymmenen aineen yhteismäärästä on esim. sinkin kohdalla $4 \%$, kuparin $2 \%$ ja koboltin ja molybdenin n. $1 \%$. Hiesu- ja hiesusavimaissa tämä yhteismäärä on kaikkein suurin (n. 1600 ppm), aito- ja hietasavessa n. $85 \%$ siitä, hietamaissa ja liejusavessa n. $2 / 3$, moreeni- ja multamaissa n. 1/2 ja turvemaissa n. 1/3 hiesumaiden sisältämistä määristä. Hiesumaiden runsaat hivenravinnevarat johtunevat, samoin kuin myös niiden runsaat pääravinnevarat näiden maiden yleensä heikosta kasvusta. 